\title{
The Anthropometric Profile and Motor Skill of Men Elite Volleyball Players
}

\author{
Nasuka Nasuka* \\ Faculty of Sport \\ Universitas Negeri Semarang \\ Semarang, Indonesia \\ *nasuka@mail.unnes.ac.id
}

\begin{abstract}
Anthropometric profile and motor skill are dominant factors influencing the performance of volleyball players. The aim of the research was to know the anthropometric profile and motor skill of the club elite players. This study was a cross sectional study involving $\mathbf{4 5}$ men elite volleyball players of Universitas Negeri Semarang volleyball club. Anthropometric measurements included body weight, body height, and Body Mass Index. Motor skill tests included vertical jump, block jump reach, spike jump reach, medicine ball throw, and 20 feet sprint. The average of body height was $182.3 \mathrm{~cm}$ (without libero) and $182.1 \mathrm{~cm}$ (with libero). The average of BMI was 21.36. The average of motor skills was $70.2 \mathrm{~cm}$ (vertical jump), $311 \mathrm{~cm}$ (block jump reach), 321.3 (spike jump reach), $4.5 \mathrm{~m}$ (medicine ball throw), and 3.1 sec (20 feet sprint). The anthropometric profile and motor skill of Universitas Negeri Semarang volleyball players were lower than international players, but better than university student volleyball club players in Indonesia.
\end{abstract}

Keywords: anthropometric, motor skill, volleyball players

\section{INTRODUCTION}

Volleyball is a sport that needed high characteristic in technical and strategic to reach the winning. The development of playing resulted variation in basic technical and high skill of playing, for example jump serve and floating serve. There are difference characteristics of physiologic and anthropometric profile of player in different level suggested the influenced these factors on volleyball player performance [1].

Anthropometric factors influenced volleyball players performance and their prestige because of the characteristic of volleyball game. The game needed a height, power, agility, flexibility and speed to build attack and defence. Motoric skill in associated volleyball game is a basic movement skill supported player to applied technical and strategy of game. For example, middle blocker must lead in terms of physical attributes overall: height, weight, reach, spike reach and block reach, which could be explained by the lowest BMI values showed [2].

The purpose of research to analyse the anthropometric and motoric skill profile of the elite volleyball player of university level compared the international player.

\section{METHOD}

\section{A. Subject}

A cross sectional study performed to 45 male players of UNNES's volleyball club. They consist of 14 main players 2015 team, 16 main players 2016 team and 15 main players 2017 team. All participants were exam by medical doctor before measurement were done included the general condition, blood pressure, heart rate and cardio pulmonary function.

\section{B. Anthropometric Measurement}

Anthropometric measurement involved body height and Body Mass Index. The body height measurement used microtoise, that valid until $0,1 \mathrm{~cm}$. An electronic weight scale was employed for body mass measurement (in the nearest 0.1 $\mathrm{kg})$. BMI was calculated as the quotient of body mass $(\mathrm{kg})$ to height squared $\left(\mathrm{m}^{2}\right)$, known Quetelet Index.

\section{Motoric Skill Measurement}

The motoric skills measurement involved vertical jump, block jump reach, spike jump reach, medicine ball throw and 20 yards sprint. Each player performed three times exercise and the highest value was taking the result.

\section{RESULTS}

The anthropometric and motoric skills of male UNNES volleyball club players presented on Table 1 and Table 2.

TABLE I. The AVERAGE OF Body HeIGHT AND Body MASS INDEX OF UNNES VOLLEYBALl CLUB'S PLAYERS

\begin{tabular}{|l|c|c|c|}
\hline \multirow{2}{*}{ Anthropometric } & \multicolumn{3}{|c|}{ Main player of } \\
\cline { 2 - 4 } & $\mathbf{2 0 1 5}(\boldsymbol{n = 1 4})$ & $\mathbf{2 0 1 6}(\boldsymbol{n = 1 6})$ & $\mathbf{2 0 1 7}(\boldsymbol{n = 1 6})$ \\
\hline Body height $(\mathrm{cm})$ & & & \\
Without Libero & $182,3 \pm 3,11$ & $182,5 \pm 5,15$ & $182,1 \pm 2,77$ \\
With Libero & $182,1 \pm 3,10$ & $182,3 \pm 5,10$ & $182,0 \pm 2,72$ \\
\hline Body mass index & $21,14 \pm 1,76$ & $22,11 \pm 1,89$ & $20,78 \pm 1,18$ \\
\hline
\end{tabular}


TABLE II. The AVERAGE OF Motoric SKILl UNNES Volleyball CLUB'S PlaYeRS

\begin{tabular}{|l|l|l|l|}
\hline \multirow{2}{*}{\multicolumn{1}{c|}{ Table Head }} & \multicolumn{3}{c|}{ Table Column Head } \\
\cline { 2 - 4 } & $\mathbf{2 0 1 5}(\boldsymbol{n = 1 4 )}$ & $\mathbf{2 0 1 6}(\boldsymbol{n = 1 6})$ & $\mathbf{2 0 1 7}(\boldsymbol{n = 1 6})$ \\
\hline Vertical jump(cm) & $70,5 \pm 5,89$ & $70,06 \pm 5,97$ & $70,2 \pm 2,45$ \\
\hline Spike reach jump(cm) & $319,9 \pm 5,05$ & $321,4 \pm 9,24$ & $322,6 \pm 5,78$ \\
\hline Block reach jump(cm) & $308,3 \pm 4,59$ & $311,5 \pm 7,92$ & $313,0 \pm 5,22$ \\
\hline Medicine ball test(M) & $4,68 \pm 0,41$ & $4,42 \pm 0,31$ & $4,41 \pm 0,33$ \\
\hline Speed 20 feet(sec) & $3,04 \pm 0,12$ & $3,14 \pm 1,15$ & $3,11 \pm 0,14$ \\
\hline
\end{tabular}

\section{DISCUSSION}

The profile of anthropometric and somatotype athlete different in the kind of sport. Anthropometric characteristic influenced the performance of volleyball players. Volleyball characteristic included skill motoric, social, competitive, intelligent, rule of law and physical fitness. The game technical included serving, passing, spiking and blocking needed high performance and skill. Cognitive skills are needed to arrange the strategy and develop the ability to control the situation during game. This included perception and concentration [3].

A volleyball team squad of eight or nine players may choose to keep two setters, two or three swing hitters, two middle hitters (who could be replaced by libero) and two back row specialists [4]. Each player not only skill in specialist position, but also skill in basic technical of volleyball, passing and serving. A setter must have specific skill in present the ball to spiker in order to build attack. Physical quality of setter included body height, speed, and ambidexterity.

A Strong-side hitter plays in the left front position. Player in this position performed attacked easier. The skills were needed a strong-side hitter included: 1) Confidence, 2) Ability to make an adjustment, 3) Ability to hit a variety of shot, and 4) good physical condition. Opposite hitter plays across the court from the strong-side hitter. The opposite hitter responsible for attacking from this position and blocking the opposite's strongsite hitter. The skills to have an opposite hitter included concentration and preparedness, and ability to self in emergence. Middle Hitter or middle blocker responsible to attack ball set in the middle of the court and is often used a decoy during points. The players who excel at this position have the following skills: good lateral movement, availability and good timing [5].

Back-row Specialist or defensive specialist emphasis on strong defensive play. A defensive specialist can enter the game in the same floor position every time as long as the coach still has substitution left. The most effective defensive specialist possessed the skills: constant readiness and immunity to pressure [5].

Volleyball game involves frequent bouts of intensive activities such as jumping, diving and lateral movement. Modern volleyball is characterized by a very high outreach of volleyball players above the net and high ball velocity on jump serve and spiking. Anthropometric factors, especial body height and body mass index, influenced the performance of volleyball player.
Body height is an important factor to support the successful technical skills and performance. A tall player is an opportunity because of their easily to conduct serving, spiking and blocking effectively. Spiking and blocking is a characteristic of volleyball game were determinate by the body height of player. Last survey presented that the average of body height an elite player are higher than novice who plays in the lower competition [1]. It is likely that vertical jump height (spike and block) influences the performance of beach volleyball players [6]. Spike jump reach and block jump reach were influenced by arm length and leg length too [7]. The average of body height men volleyball player in Olympic Game were suggested in table III.

TABle III. The Average of Body Height Men Volleyball PlayeR IN OLYMPIC GAMES 2016

\begin{tabular}{|l|l|l|l|l|l|}
\hline \multirow{2}{*}{ Rank } & \multirow{2}{*}{ Nation } & \multirow{2}{*}{$\mathbf{n}$} & \multicolumn{3}{|c|}{ Average of body height (cm) } \\
\cline { 4 - 6 } & & & $\begin{array}{c}\text { Without } \\
\text { libero }\end{array}$ & With libero & $\begin{array}{c}\text { Libero's } \\
\text { height }\end{array}$ \\
\hline 1 & Brazil & 12 & 199.55 & 198.25 & 184.00 \\
\hline 2 & Italy & 12 & 200.00 & 197.08 & 185.00 \\
\hline 3 & USA & 12 & 199.45 & 198.17 & 164.00 \\
\hline 4 & Russia & 12 & 201.18 & 199.67 & 183.00 \\
\hline 5 & Argentina & 12 & 196.64 & 195.58 & 184.00 \\
\hline 6 & Canada & 12 & 199.90 & 198.00 & 184.00 \\
\hline 7 & Iran & 12 & 198.00 & 195.83 & 172.00 \\
\hline 8 & Poland & 12 & 198.80 & 198.17 & 184.00 \\
\hline 9 & Egypt & 12 & 197.73 & 196.92 & 188.00 \\
\hline 10 & France & 12 & 197.30 & 196.67 & 188.00 \\
\hline 11 & Cuba & 12 & 195.40 & 193.92 & 183.00 \\
\hline 12 & Mexico & 12 & 194.18 & 193.83 & 190.00 \\
\hline
\end{tabular}

Source: www.rio2016.fivb.com

In comparison with players who playing in international competition, the subject's height were below. The height implicated to body mass index associated with the cardiorespiratory capacity [8]. The body mass index also influenced the performance of any game player like polo [9], and volleyball [10]. The high value of body mass index decreased cardiorespiratory capacity of men and also women. It associated with body fat composition and the individual somatotype. BMI are associated with reduced physical fitness, as it has been indicated by research conducted chiefly on young populations. BMI have negatively correlated with physical fitness [11,12]. Several studies have identified the anthropometric profile, mainly the somatotype of athletes from various sports. Anthropometric characteristics are believed to influence the performance in volleyball players, have also conducted studies to determine the measures that were more related to the performance of volleyball players in different positions on the field. The logical reason based on characteristic of volleyball game: ectomorfism type given opportunity because of their easy to move, jump and reaction [13].

Important skills to have a volleyballs player were supported by skills of basic movement or motoric skills. The motoric skills were developed standing reach, standing vertical jump, approach jump, ball throw, for-line agility run and athletic 
catch [4]. Vertical jump ability is a basic motoric skill appear the explosive power of lower extremity muscle. This competence is very important to build an attack to opposite team, via jumping serve and spiking, or defence from their attack, via blocking. Vertical jump exercise intensively influenced the elite volleyball player performance $[14,15]$. The higher vertical jump given a great chance to perform a dip jump serve and spike. The dip spike given difficulty for the opponent's defence.

Spiking and blocking successfully is crucial feature of winning team in volleyball game. Spiking is a volleyball approaches and strategies to jump high and hit hard. This technic was resulted from explosiveness, agility, coordination and the time of motor reaction. Spike jump reach is a highest hand reach when a player jump with starting. Elite players could reach more than $70 \mathrm{~cm}$ above the net (Table IV). These motoric skills given the convenience to spike, block and serve.

Volleyball techniques for blocking involve learning to see the court and making quick decisions at the net when preparing to block. Blockers need good balance and stability to develop a consistent block jump. Volleyball players with ankle functional instability showed decreased peroneus longus activity before ground impact that may predispose them to repetitive sprains and explain their "giving way" sensation, since peroneus longus is the main ankle evertor and an important stabilizer against sudden and excessive inversion. This instability decreased successfully of blocking because of alteration of neuromuscular control [16]. The study clearly demonstrated that in an elite population of volleyball players, stretchshortening cycle performance and the ability to tolerate high stretch loads, as in the depth jump, is critical to performance in the jumps associated with volleyball performance [17]. Table IV appear spike jump reach and block jump reach profile of elite volleyball players who play in Olympic Games 2016 Rio de Janeiro.

TABLE IV. SPIKE JUMP REACH AND BLOCK JUMP REACH MEN VOLLEYBALl PLAYER IN OLYMPIC GAMES 2016

\begin{tabular}{|l|l|l|l|l|}
\hline Rank & Nation & $\mathbf{n}$ & $\begin{array}{c}\text { Spike jump } \\
(\mathbf{c m})\end{array}$ & $\begin{array}{c}\text { Block jump } \\
(\mathbf{c m})\end{array}$ \\
\hline 1 & Brazil & 12 & 338,08 & 317,58 \\
\hline 2 & Italy & 12 & 343,42 & 322,83 \\
\hline 3 & USA & 12 & 348,42 & 328,92 \\
\hline 4 & Russia & 12 & 343,67 & 327,83 \\
\hline 5 & Argentina & 12 & 343,08 & 324,50 \\
\hline 6 & Canada & 12 & 347,83 & 321,67 \\
\hline 7 & Iran & 12 & 341,92 & 323,08 \\
\hline 8 & Poland & 12 & 344,25 & 319,83 \\
\hline 9 & Egypt & 12 & 337,92 & 326,17 \\
\hline 10 & France & 12 & 347,33 & 326,58 \\
\hline 11 & Cuba & 12 & 344,58 & 332,17 \\
\hline 12 & Mexico & 12 & 338,67 & 327,17 \\
\hline
\end{tabular}

The ability of elite volleyball player to conduct vertical jump, spike jump and block jump were lower in comparison with elite player in FIVB and Olympic competition. The race or genetic population influenced the anthropometric profile and motoric skills in associated with the size of muscle, bone and body composition. The different anthropometric and motoric skills profile of level competition suggested that anthropometric and motoric skill determined the level of plays.

\section{CONCLUSIONS}

The difference level of competition needs the difference level of performance. The anthropometric and motoric skill profile of volleyball players were lower than international players, but better than university student volleyball club players in Indonesia.

\section{REFERENCES}

[1] T.J. Gabbett and B. Georgieff, "Physiological and anthropometric characteristics of australian junior national, state, and novice volleyball players", International Journal of Sport Physiology and Performance, vol. 1, pp. 95-107, 2007.

[2] A.M. Sánchez, J.C. Morante and A. Ureña, "The middle blocker in volleyball: a systematic review. journal of human sport and exercise," 2018.

[3] R. Martens, "Successful coaching," 3rd ed., United States: Human Kinetics, 2004.

[4] B. Miller, "The volleyball handbook, winning essentials for players and coaches," Champaign: HumanKinetics, 2005.

[5] G. Bach and National Alliance for Young Sport, "Coaching volleyball for dummies,” Indiana: Wiley Publishing Inc, 2009.

[6] G.R. Batista, R.F. De Araujo and R.O. Guerra, "Comparison between vertical jumps of high performance athletes on the Brazilian men's beach volleyball team," J Sports Med Phys Fitness, vol. 48(2), pp. 172-176, 2008.

[7] Nasuka and E.N. Priambodo, "Hubungan panjang lengan dan panjang tungkai dengan kemampuan vertikal jump,spike jump reach dan block jump reach remaja putra," Jurnal Media Ilmu Keolahragaan Indonesia, vol. 7(1), Juli 2017.

[8] S.G. Lakoski, C.E. Barlow, S.W. Farrell, J.D. Berry, J.R. Marrow and W.L. Haskell, "Impact of body mass index, physical activity, and other clinical factors on cardiorespiratory fitness (from the cooper center longitudinal study)," The American Journal of Cardiology, pp. 34-39, 2011.

[9] H. Vila, C. Ferragut, F.M. Argudo, J.A. Abraldes, N. Rodriquez and F. Alacid, "Relationship between anthropometric parameters and throwing velocity in water polo players," Journal of Human Sport and Exercise, vol. 4(1), pp. 57-68, 2009.

[10] G.G. Malousaris, N.K. Bergeles, K.G. Barzouka, I.A. Bayios, G.P. Nassis and M.D. Koskolou, "Somatotype, size and body composition of competitive female volleyball players," Journal of Science and Medicine in Sport, vol. 11, pp. 337-344, 2008.

[11] M. Brunet, J.P. Chaput and A. Tremblay, "The association between low physical fitness and high body mass index or waist circumference is increasing with age in children: the 'Que'bec en Forme' Project," International Journal of Obesity, vol. 31, pp. 637-643, 2007.

[12] P.T. Nikolaidis, "Elevated body mass index and body fat percentage are associated with decreased physical fitness in adolescent and adult female volleyball players," J Res Med Sci, vol. 18(1), pp. 22-26, 2013.

[13] J.C. Zary, V.M. Reis, A. Rouboa, A.J. Silva, P.R. Fernandes and J.F. Filho, "The somatotype and dermatoglyphic profiles of adult, junior and juvenile male Brazilian top-level volleyball player,". Science and Sport, vol. 25, pp. 146-152, 2010.

[14] M.P. Riggs and J.M. Sheppard, "The relative importance of strength and power qualities to vertical jump height of elite beach volleyball players during the counter-movement and squat jump," Journal of Human Sport and Exercise, vol. 4(3), pp. 221-236, 2009.

[15] J.M. Sheppard, A.A. Dingley, Jansen, W. Spratford, D.W. Chapman and R.U. Newton, "The effect of assisted jumping on vertical jump height in high-performance volleyball players," Journal of Scienceand Medicine in Sport, vol. 14, pp. 85-89, 2010. 


\section{PRESS}

[17] J.M. Sheppard, J.B. Cronin, T.J. Gabbett, M.R. McGuigan, N. Etxebarria and R.U. Newton, "Relative importance of strength, power, and anthropometric beasures to jump performance of elite volleyball players," J Strength Cond Res, vol. 22(3), pp. 758-65 , 2008. blocking," Journal of Electromyography and Kinesiology, vol. 19, pp 84-93, 2007. 